\title{
Prey selection in the trap-nesting wasp Trypoxylon (Trypargilum) opacum Brèthes (Hymenprtera; Crabronidae)
}

\author{
Buschini, MLT. ${ }^{\mathrm{a}}$, Borba, NA. ${ }^{\mathrm{a} *}$ and Brescovit, AD. ${ }^{\mathrm{b} *}$ \\ ${ }^{\text {a } D e p a r t a m e n t o ~ d e ~ B i o l o g i a, ~ U n i v e r s i d a d e ~ E s t a d u a l ~ d o ~ C e n t r o-O e s t e ~-~ U N I C E N T R O, ~}$ \\ Rua Presidente Zacarias, 875, CEP 85010-990, Guarapuava, PR, Brazil \\ 'Laboratório de Artrópodes Peçonhentos, Instituto Butantan, \\ Av. Brasil, 1500, CEP 05503-900, São Paulo, SP, Brazil \\ *e-mail: isatunes@yahoo.com.br, neideaugusta@yahoo.com.br, adbresc@terra.com.br \\ Received March 24, 2009 - Accepted June 24, 2009 - Distributed August 31, 2010
}

(With 5 figures)

\begin{abstract}
The purpose of our research was to document and discuss the temporal patterns of prey use shown by the trap-nesting wasp Trypoxylon opacum in two different habitats in Southern Brazil. It was carried out from December 2001 to December 2004. Twenty nine species belonging to five families of spiders were captured by T. opacum. Araneidae was the most captured family and has been strongly represented by the genus Eustala. Through Bray-Curtis's coefficient and the unweighted pair group method average (UPGMA), the spiders can be divided into three groups: the smaller group includes the most abundant species (Alpaida sp2, Bertrana rufostriata, Eustala sp1, Eustala sp2, Eustala sp3 and Eustala sp4), the second group includes species with intermediate abundance (Alpaida, Alpaida gracia and Mangora sp2), and the third and largest group includes the less abundant species, (Acacesia villalobosi, Alpaida argenata, Alpaida sp1, Araneus blumenau, Araneus sicki, Crysometa boraceia, Crysometa sp3, Eustala sp8, Eustala sp11, Larinia t-notata, Mangora sp1, Ocrepeira aff gnomo, Sanogasta sp., Sanogasta sp2, Sanogasta sp3, Salticidae sp2, Theridion sp1, Theridion sp2, Wagneriana eupalaestris, Wagneriana iguape). Of 1,053 identified spiders, 362 were captured in the grassland areas and 691 in the swamp, since T. opacum built nests only in these two habitats. The diversity, richness and evenness of spiders in T. opacum nests were higher in grassland than in the swamp.
\end{abstract}

Keywords: Crabronidae, Trypoxylon opacum, spider, prey use.

\section{Seleção de presas por vespa que nidifica em ninhos-armadilha Trypoxylon (Trypargilum) opacum Brèthes (Hymenprtera; Crabronidae)}

\section{Resumo}

O objetivo desta pesquisa foi documentar e discutir o padrão temporal de uso de presas por Trypoxylon opacum em dois ambientes diferentes no Sul do Brasil. Ela foi realizada de dezembro de 2001 a dezembro de 2004. Vinte e nove espécies de aranhas pertencentes a cinco famílias foram capturadas por Trypoxylon opacum. Araneidae foi a família mais capturada e foi fortemente representada pelo gênero Eustala. Pelo coeficiente de Bray-Curtis e pela análise de agrupamento, (UPGMA) as aranhas foram divididas em três grupos: o menor deles, incluindo as aranhas mais abundantes na dieta de T. opacum (Alpaida sp2, Bertrana rufostriata, Eustala sp1, Eustala sp2, Eustala sp3 and Eustala sp4); o segundo com as espécies cujas abundâncias foram intermediárias (Alpaida, Alpaida gracia and Mangora sp2); e o terceiro e maior grupo com as espécies pouco abundantes (Acacesia villalobosi, Alpaida argenata, Alpaida sp1, Araneus blumenau, Araneus sicki, Crysometa boraceia, Crysometa sp3, Eustala sp8, Eustala sp11, Larinia t-notata, Mangora sp1, Ocrepeira aff gnomo, Sanogasta sp., Sanogasta sp2, Sanogasta sp3, Salticidae sp2, Theridion sp1, Theridion sp2, Wagneriana eupalaestris, Wagneriana iguape). Das 1.053 aranhas identificadas, 362 foram capturadas em área de campos naturais e 691 em área de várzea, visto que T. opacum fundou ninhos apenas nestes ambientes. A diversidade, a riqueza e a equitabilidade de aranhas nos ninhos de T. opacum foram maiores nas áreas de campos do que naquelas de várzeas.

Palavras-chave: Crabronidae, Trypoxylon opacum, aranhas, uso de presas. 


\section{Introduction}

Most wasps belong to the families Pompilidae, Sphecidae, Crabronidae, use terrestrial arthropods as food supply for their offspring. Most of them paralyse their prey, drag it to a burrow, and lay one egg on the prey item. When the wasp larva hatches, it feeds on the paralysed host (Coville, 1987). Their efficiency as hunters is enhanced by their ability to walk on plants covered by wax bloom (Eigenbrode et al., 2000) and by their ability to learn (Jones et al., 2002).

Predatory wasps may exert selective pressures on their prey, and studies of the hunting mechanisms and ecosystem impacts of predation by solitary wasps may provide insight into the evolutionary mechanisms, defining the econiches of generalist and specialist predators (Evans, 1963).

Solitary nesting sphecids, a group including both Crabronidae and Sphecidae wasps, show a high degree of prey specialisation ranging from one single species to many species of one single insect family or order (O'Neill, 2001). Moreover, individuals within a population might vary their resource use because they inhabit different microhabitats (Coville, 1987).

In Trypoxylon and in other genera in the family Crabronidae and in the related family Sphecidae, females hunt spiders to provide food for their larvae (Coville, 1987). These wasps capture a wide range of spider taxa, including orb-weaving spiders (Araneidae, Tetragnathidae, Nephilidae), araneoid sheet web weavers (Theridiidae), and even several taxa that usually do not use webs to capture prey (Lycosidae, Oxyopidae, Clubionidae) (Camillo and Brescovit, 1999a, 1999b; Blackledge et al., 2003; Buschini and Wolff, 2006; Buschini et al., 2006). They have great flexibility in selecting the spider's size, since they can supply the nutrients required for larval development by depositing several small specimens in each cell (Gonzaga and Vasconcellos-Neto, 2005).

A number of biological traits of prey can be relevant during hunting, in particular, anti-predator mechanisms. Within the large range of defensive mechanisms that have evolved in spiders in response to predation (Cloudsley-Thompson, 1995), the three-dimensional webs of the Orbiculariae are probably among the most effective against capture by hunting-wasps (Blackledge et al., 2003). Moreover, one of the main factors inducing a particular prey capture is the availability of suitable prey in the locality. Studies have demonstrated that prey capture might be related to either the availability of prey or the prey-predator size relationship, or to the hunting behaviour, in particular, the preferred hunting habitat (O'Brien, 1982; Weaving, 1988; Polidori et al., 2005).

Few studies concerning the temporal patterns of prey selection shown by Trypoxylon species have been undertaken in Brazil (Camillo and Brescovit, 1999a, 1999b; Camillo and Brescovit, 2000). Buschini et al. (2008) investigated the patterns of prey selection of Trypoxylon lactitarse Saussure in the Parque Municipal das Araucárias. According to these authors fifty three species of spiders belonging to seven families were captured by T. lactitarse and Araneidae was the most captured family. Trypoxylon opacum also occurs in this Park and like T. lactitarse it is one of the most abundant species (Buschini and Woiski, 2008), although it is a poorly known species of solitary wasp. The only investigation on this species was carried out by Buschini and Wolff (2006) who reported on several aspects of its biology. In the light of this, the purpose of our research was to verify if the prey spectrum of Trypoxylon opacum varies across nesting seasons and between two different habitats.

\section{Methods}

\subsection{Study areas}

This study was carried out in the Parque Municipal das Araucárias, in the municipality of Guarapuava, State of Paraná, Southern Brazil (25 23' S and 51 ${ }^{\circ} 27^{\prime} \mathrm{W}, 1,120 \mathrm{~m}$ of altitude). This area is characterised by a wet, cool season. Hoar frosts are common and severe. During the warmest months the average temperature is less than $22^{\circ} \mathrm{C}$.

Collections were carried out from December 2001 to December 2004 and were concentrated in a very heterogeneous site, with araucaria forests, swamps and grasslands. The grasslands are characterised, physionomically, by areas of low grasses and no bushes. Species belonging to Cyperaceae, Leguminosae, Verbenaceae, Compositae and Apiaceae are the main ones found in this habitat. In Araucaria forest, there is a predominance of Araucaria angustifolia (Bertolini) (Coniferae; Araucariaceae) and in swamps, which are located in the lowest regions of the park, there are mainly grasses and Compositae.

\subsection{Sampling program}

Nests of T. opacum were obtained using trap-nests made out of $25 \times 20 \times 120 \mathrm{~mm}$ wooden blocks (Araucaria angustifolia), drilled longitudinally to a depth of $80 \mathrm{~mm}$ with 7.0, 10.0, and $13.0 \mathrm{~mm}$ aperture diameters. Before being drilled, they were sawed in half longitudinally and then held together with adhesive tape to allow the examination of the cavities when opened.

For each habitat, two areas were studied, with 2 transects per area and 4 sampling stations per transect. Twelve trap-nests were placed at each sampling station, four of each opening diameter, totaling 576 trap-nests which were constantly kept in the field. They was placed at $1.5 \mathrm{~m}$ above the ground and inspected every two weeks. In each inspection, all completed wasps nests were removed and immediately replaced with empty traps of the same diameter. The nests were then brought to the laboratory in order to investigate their contents. If live eggs and/or larvae were present, the nest was closed to allow the completion of the life-cycle and the emergence of the adults. All spiders from cells with dead eggs or larvae were removed and identified. Spider abundance was calculated according to sex, development stage, family, genus and species. 


\subsection{Statistical analyses}

Three indices were used to investigate the diversity of spider species in the diet of T. opacum in each of the habitats where they founded their nests: species richness (Margalef's index), Shannon-Wiener diversity and species evenness (Pielou's J index) (Ludwig and Reynolds, 1988).

To investigate the similarity between spider species abundances in T.opacum's diet they were grouped according to their abundances, using the Bray-Curtis coefficient, as
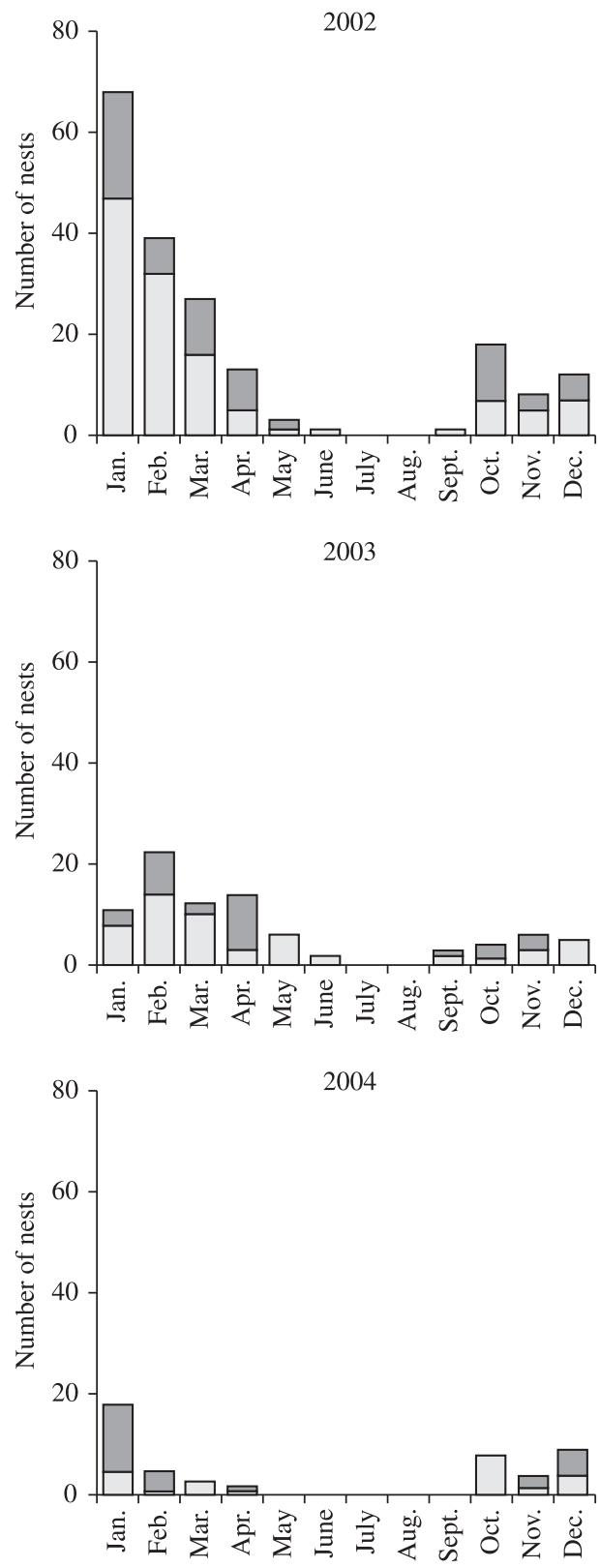

$\square$ Grassland $\square$ Swamp $\square$ Forest

Figure 1. Seasonal variation in the number of nests of T. opacum obtained monthly, in different habitats, from December 2001 to December 2004. a metric and the unweighted pair group method average (UPGMA) as the clustering method (Ludwig and Reynolds, 1988). The cophenetic coefficient of correlation was calculated in order to assess the appropriateness of the dendrograms. Similarity matrices were compared using the Mantel test (Mantel, 1967).

Spider species dominance was calculated according to Palma (1975):

$\mathrm{D}=($ Abundance of species $\div$ Total abundance $) \times 100$

if $\mathrm{D}>5 \%$, the species is termed a dominant species; if $2.5 \%<\mathrm{D}<5 \%$, the species is termed an accessory species; if $\mathrm{D}<2.5 \%$, the species is termed an incidental species.

Chi-square tests were used to test the null hypothesis related to the proportion of collected juveniles, males and females according to the BioStat 5.0 programme (Ayres et al., 2003).

\section{Results}

\subsection{Nesting activity of Trypoxylon opacum in different habitats}

A total of 312 T. opacum nests were collected. Nests were more frequently found in the grassland than in the swamp areas. Trypoxylon opacum did not build nests in araucaria forest. They were built mainly during the summer (between December and March), during high temperature periods (Figures 1 and 2).

\subsection{Species of spiders collected by Trypoxylon opacum}

Twenty nine species of spiders belonging to 4 families were captured by T. opacum. Araneidae was the most captured family with 1,042 individuals (99\%), distributed among 9 genera (69\%) and 21 species (72\%). Although the majority of the individuals $(n=850)$ belonging to this family were juveniles and could not be identified, of species identified Eustala sp2 was the most frequently captured species with 34 individuals (Table 1). This species was

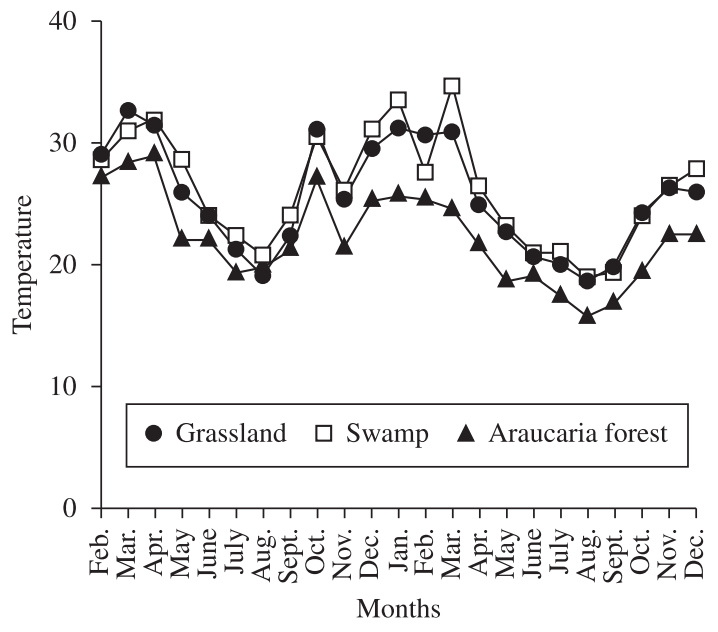

Figure 2. Air temperature $\left({ }^{\circ} \mathrm{C}\right)$ in different habitats from February 2002 to December 2003 (Buschini et al., 2006). 
captured throughout 6 months, most frequently during January, February and April. Bertrana rufostriata, the second most frequent species with 30 individuals, was captured throughout 4 months, most frequently in April. Eustala sp1 also with 30 individuals captured, was most frequent in January, March and April (Figure 3).

Tetragnathidae was the second most captured family, with 4 individuals, distributed in 1 genus and 2 species. Crysometa boraceia was the most captured species with 3 individuals collected during the months of January and April.
Anyphaenidae, represented by 3 individuals, belonging to the same genus and 3 species, Theridiidae also with 3 individuals to the same genus and Salticidae with a single individual, were the other families captured by T. opacum.

\subsection{Species of spiders in the grassland and swamp} areas

Of 1,053 spiders, 362 were captured in grassland areas and 691 in swamp. Of identified species Alpaida sp2, Alpaida gracia, Eustala sp1, Eustala sp2, Eustala sp3, Eustala sp4 and Crysometa boraceia were common to the two habitats.

Table 1. Number of juvenile (J), female (F) and male (M) spiders collected by T. opacum in different habitats.

\begin{tabular}{|c|c|c|c|c|c|c|}
\hline \multirow[t]{2}{*}{ Species } & \multicolumn{3}{|c|}{ Grassland } & \multicolumn{3}{|c|}{ Swamp } \\
\hline & $\mathbf{J}$ & M & $\mathbf{F}$ & $\mathbf{J}$ & M & $\mathbf{F}$ \\
\hline
\end{tabular}

ANYPHAENIDAE Bertkau, 1878

Sanogasta sp Mello-Leitão, 1941

Sanogasta $\mathrm{sp} 2$

Sanogasta $\mathrm{sp} 3$

ARANEIDAE Simon, 1895

850

Acacesia villalobosi Glueck, 1994

Alpaida O. P.-Cambridge, 1889

Alpaida argenata

Alpaida gracia Levi, 1988

Alpaida sp1 Cambridge, 1889

Alpaida sp2

Araneus blumenau Levi, 1991

Araneus sicki Levi, 1991

Bertrana rufostriata Simon, 1893

Eustala sp1 Simon, 1895

Eustala sp2

Eustala sp3

Eustala sp4

Eustala sp8

Eustala sp11

Larinia t-notata (Tullgren, 1905)

Mangora sp1 O. P.-Cambridge, 1889

Mangora sp2

Ocrepeira aff gnomo (Mello-Leitão, 1943)

Wagneriana eupalaestris Levi, 1991

Wagneriana iguape Levi, 1991

1$$
2
$$

1

1

2

2

$\begin{array}{cccc}8 & & & 30 \\ 3 & 2 & 2 & 8 \\ 10 & 3 & 5 & 5 \\ & & 1 & \end{array}$

15 5

\section{0}

$\begin{array}{lll} & & 1 \\ 1 & 1 & 1 \\ & 1\end{array}$

SALTICIDAE Blackwall, 1841

2

Crysometa boraceia Levi, 1986

Crysometa sp3 Simon, 1894

THERIDIIDAE Sundevall, 1833

Theridion sp1 Walckenaer, 1805

Theridion $\mathrm{sp} 2$ sp2

TETRAGNATHIDAE Menge, 1866

Total 
Sanogasta sp., Sanogasta sp2, Sanogasta sp3, Acacesia villalobosi, Alpaida sp1, Araneus blumenau, Araneus sicki, Larinia t-notata, Mangora sp1, Mangora sp2, Ocrepeira aff gnomo, Wagneriana eupalaestris, Wagneriana iguape and one individual of the family Salticidae were captured only in grassland areas, while Alpaida, Bertrana rufostriata,

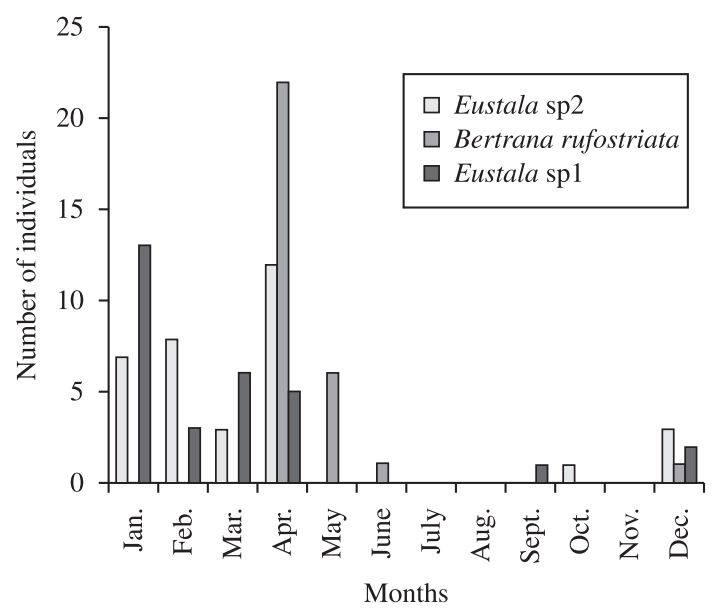

Figure 3. Monthly number of prey species most frequently collected by $T$. opacum.
Eustala $\mathrm{sp}_{8}$, Eustala $\mathrm{sp} 11$, Crysometa $\mathrm{sp} 3$, Theridion $\mathrm{sp} 1$ e Theridion sp2 occurred only in swamp. Eustala sp4 was the most captured species in swamp $(n=21)$, while Eustala sp1 was the most collected species in the grassland areas $(\mathrm{n}=21)$.

\subsection{Spider diversity and similarity}

The diversity of spider species used by $T$. opacum was higher in grassland $\left(\mathrm{H}^{\prime}=1.003\right)$ than in swamp area $\left(\mathrm{H}^{\prime}=0.909\right)$. Although the grasslands presented higher spider species richness $\left(D_{\mathrm{Mg}}=10.773\right)$ than the swamp area $\left(D_{M g}=6.819\right)$, the evenness was higher in swamp area $\left(\mathrm{J}^{\prime}=0.773\right)$ than in the grasslands $\left(\mathrm{J}^{\prime}=0.747\right)$.

Figure 4 shows that, not taking into account the different habitats, identified spiders can be divided into 3 groups according to abundance $(r=0.962)$. The smaller group includes the most abundant species (Alpaida $\mathrm{sp} 2$, Bertrana rufostriata, Eustala sp1, Eustala sp2, Eustala sp3 and Eustala sp4), i.e., those most commonly captured by T. opacum. The second group includes species represented by a range of 7 to 10 individuals (Alpaida, Alpaida gracia and Mangora sp2). The third and largest group includes the less abundant species, represented by a range of 1 to 3 individuals (Sanogasta sp, Sanogasta sp2, Sanogasta sp3, Theridion sp2, Crysometa sp3, Salticidae

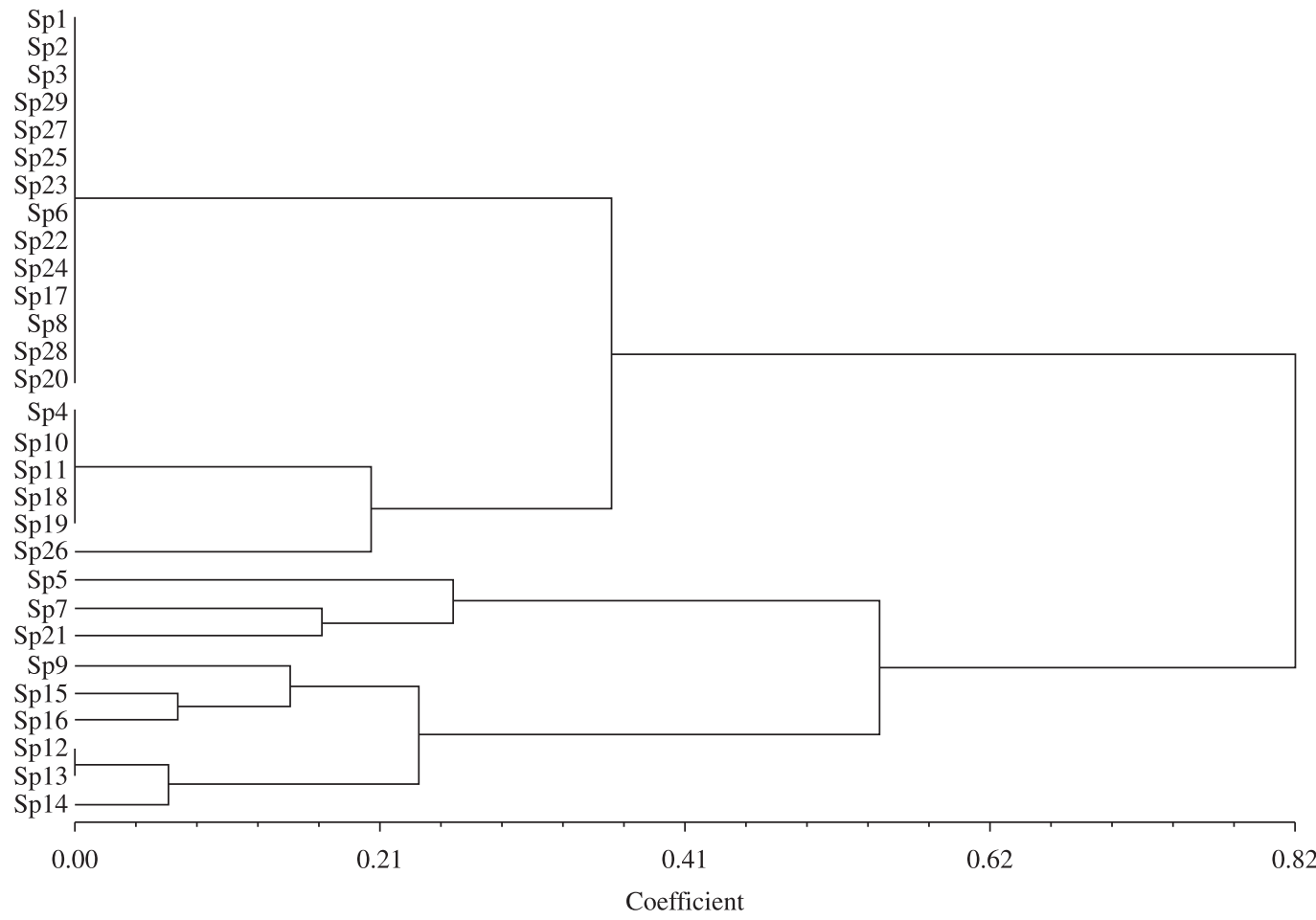

Figure 4. Dissimilarity dendrogram between spiders species related to their abundances on T. opacum diet: $\mathrm{Sp} 1$ = Sanogasta sp.; Sp2 = Sanogasta sp2; Sp3 = Sanogasta sp3; Sp4 = Acacesia villalobosi; Sp5 = Alpaida ; Sp6 = Alpaida argenata $; \mathrm{Sp} 7=$ Alpaida gracia $; \mathrm{Sp} 8=$ Alpaida $\mathrm{sp} 1 ; \mathrm{Sp} 9=$ Alpaida $\mathrm{sp} 2 ; \mathrm{Sp} 10=$ Araneus blumenau$;$ $\mathrm{Sp} 11=$ Araneus sicki $; \mathrm{Sp} 12=$ Bertrana rufostriata $; \mathrm{Sp} 13=$ Eustala $\mathrm{sp} 1 ; \mathrm{Sp} 14=$ Eustala $\mathrm{sp} 2 ; \mathrm{Sp} 15=$ Eustala $\mathrm{sp} 3 ; \mathrm{Sp} 16=$ Eustala $\mathrm{sp} 4 ; \mathrm{Sp} 17=$ Eustala $\mathrm{sp}_{8} ; \mathrm{Sp} 18=$ Eustala $\mathrm{sp} 11 ; \mathrm{Sp} 19=$ Larinia -notata $; \mathrm{Sp} 20=$ Mangora $\mathrm{sp} 1 ; \mathrm{Sp} 21=$ Mangora $\mathrm{sp} 2 ;$ Sp22 = Ocrepeira aff gnomo $;$ Sp23 = Wagneriana eupalaestris; Sp24 = Wagneriana iguape $;$ Sp25 = Salticidae sp2; Sp26 = Crysometa boraceia $; \mathrm{Sp} 27=$ Crysometa $\mathrm{sp} 3 ; \mathrm{Sp} 28=$ Theridion $\mathrm{sp} 1 ; \mathrm{Sp} 29=$ Theridion $\mathrm{sp} 2$. 
sp2, Wagneriana eupalaestris, Ocrepeira aff gnomo, Eustala $\mathrm{sp8}$, Alpaida argenata, Wagneriana iguape, Alpaida sp1, Theridion sp1, Mangora sp1, Araneus sicki, Acacesia villalobosi, Araneus blumenau, Eustala sp11, Larinia t-notata and Crysometa boraceia). A similar pattern emerged from the dominance indices, with the groups of dominant, accessory and accidental species (Table 2).

3.5. Number of juveniles, males and females used by Trypoxylon opacum

A total of 900 juvenile spiders (86\%), 107 females (10\%) and 46 males (4\%) were captured by T. opacum. These proportions are significantly different between them (Table 3).

Juveniles were present throughout the 10 month sampling period, but were most frequent in January (18\%), April (23\%) and May (15\%). Females were captured during 8 months, being most frequent in January (14\%), February (23\%) and April (39\%). Males were captured during 7 months and were most frequent in January (30\%), February (17\%) and April (26\%) (Figure 5).

\section{Discussion}

Prey of $T$. opacum were almost exclusively araneid spiders. Similar data has been obtained for other species of Trypoxylon (Camillo and Brescovit, 1999a, 1999b; 2000; Coville, 1981, 1987; Rehnberg, 1987; Garcia and Adis, 1995; Buschini and Wolff, 2006; Araújo and Gonzaga, 2007; Buschini et al., 2008).

Buschini et al. (2008) studied the prey selection pattern of T. lactitarse also in the Parque Municipal das Aruacárias. These authors observed a pattern similar to that of T. opacum, with Araneidae and the genus Eustala being the most captured, even though T. lactitarse captured twenty four species more than T. opacum. It is interesting that, in addition to nidifying in both field and swamp areas during the same period as T. opacum, $T$. lactitarse also nidifies in forest areas, where Alpaida and Acacesia were also frequently captured. The genus Bertrana was the second most used by T. opacum, but not by T. lactitarse, that used more spiders of the genus Araneus in field and swamp areas.

Another abundant species in this park is Trypoxylon agamemnon Richards. This species nidifies solely in forest areas (Buschini and Farjardo, in press) and captures almost exclusively wandering spiders of the family Anyphaenidae and genus Teudis. Although Araneidae is the second most frequent family in the diet of this wasp, the genus Eustala wasn't very used.

Camillo and Brescovit (1999a) studied spiders captured by $T$. lactitarse in three different regions of Southeastern Brazil. Spiders belonging to the family Araneidae (96.6\%) were also most frequently captured. They used the Shannon-Wiener index to investigate the amplitude of the reproductive niche of this wasp in the different localities. The values obtained in the three areas were: $\mathrm{H}^{\prime}=2.24, \mathrm{H}^{\prime}=2.72 \mathrm{e} \mathrm{H}^{\prime}=1.76$. Although in the present study the Shannon-Wiener index was used to evaluate the diversity of spiders in the diet of T. opacum in different habitats, the results can be compared to those of Camillo and Brescovit (1999), since they were obtained in a similar manner. For T. opacum the value obtained for the field was $\mathrm{H}^{\prime}=1.00$ and for the swamp $\mathrm{H}^{\prime}=0.91$. This indicates a lower amplitude than that obtained by these authors for T. lactitarse. Considering the results obtained by Buschini et. al. (2008), using the same index for $T$. lactitarse, the values obtained in araucária forest, field and swamp areas were $\mathrm{H}^{\prime}=1.00, \mathrm{H}^{\prime}=0.97$ and $\mathrm{H}^{\prime}=1.16$, respectively. These values were similar to those obtained for

Table 2. List of spider species and their respective dominance indices.

\begin{tabular}{|c|c|c|}
\hline Family/species & $\begin{array}{c}\text { Dominance } \\
\text { index (D) }\end{array}$ & $\begin{array}{l}\text { Dominance } \\
\text { classification }\end{array}$ \\
\hline \multicolumn{3}{|l|}{ ANYPHAENIDAE } \\
\hline Sanogasta sp1 & 0.5 & accidental \\
\hline Sanogasta $\mathrm{sp} 2$ & 0.5 & accidental \\
\hline Sanogasta sp3 & 0.5 & accidental \\
\hline \multicolumn{3}{|l|}{ ARANEIDAE } \\
\hline Acacesia villalobosi & 1.0 & accidental \\
\hline Alpaida & 5.0 & accessory \\
\hline Alpaida argenata & 0.5 & accidental \\
\hline Alpaida gracia & 2.5 & accessory \\
\hline Alpaida $\mathrm{sp} 1$ & 0.5 & accidental \\
\hline Alpaida $\mathrm{sp} 2$ & 7.9 & dominant \\
\hline Araneus blumenau & 1.0 & accidental \\
\hline Araneus sicki & 1.0 & accidental \\
\hline Bertrana rufostriata & 14.9 & dominant \\
\hline Eustala $\mathrm{sp} 1$ & 14.9 & dominant \\
\hline Eustala sp2 & 16.8 & dominant \\
\hline Eustala sp3 & 9.9 & dominant \\
\hline Eustala sp4 & 11.4 & dominant \\
\hline Eustala $\mathrm{sp}_{8}$ & 0.5 & accidental \\
\hline Eustala sp11 & 1.0 & accidental \\
\hline Larinia $t$-notata & 1.0 & accidental \\
\hline Mangora sp1 & 0.5 & accidental \\
\hline Mangora sp2 & 3.5 & accessory \\
\hline Ocrepeira aff gnomo & 0.5 & accidental \\
\hline Wagneriana eupalaestris & 0.5 & accidental \\
\hline Wagneriana iguape & 0.5 & accidental \\
\hline \multicolumn{3}{|l|}{ SALTICIDAE } \\
\hline $\mathrm{sp} 2$ & 0.5 & accidental \\
\hline \multicolumn{3}{|l|}{ TETRAGNATHIDAE } \\
\hline Crysometa boraceia & 1.5 & accidental \\
\hline Crysometa sp3 & 0.5 & accidental \\
\hline \multicolumn{3}{|l|}{ THERIDIIDAE } \\
\hline Theridion sp1 & 0.5 & accidental \\
\hline Theridion $\mathrm{sp} 2$ & 0.5 & accidental \\
\hline
\end{tabular}


Table 3. Qui-square test between the proportions of juveniles, females and males used by T. opacum in its diet.

\begin{tabular}{lcc}
\hline \multicolumn{1}{c}{ Comparisons } & $\begin{array}{c}\text { Qui-square } \\
\text { values }\end{array}$ & Probabilities \\
\hline Juveniles $\times$ Females & 55.44 & $\mathrm{p}<0.001$ \\
Juveniles $\times$ Males & 62.80 & $\mathrm{p}<0.001$ \\
Females $\times$ Males & 7.36 & $\mathrm{p}<0.001$ \\
\hline
\end{tabular}

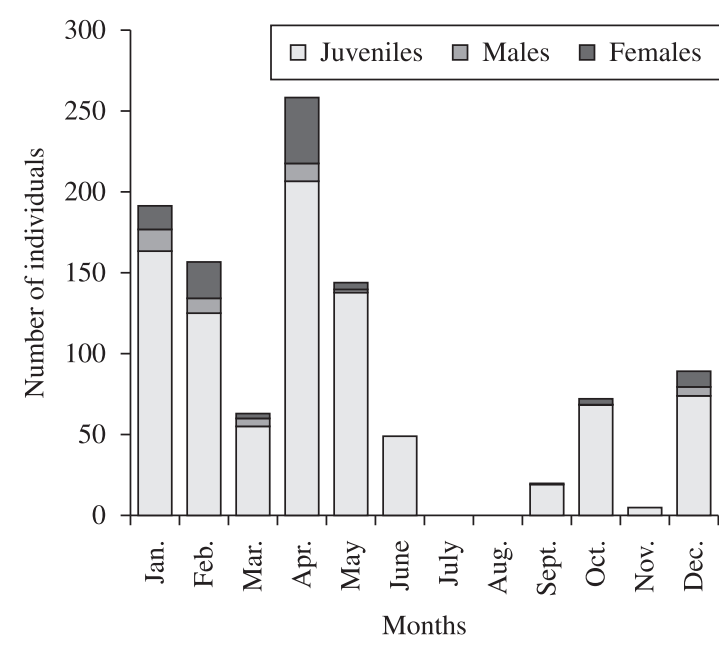

Figure 5. Monthly number of juveniles, males and females of the spiders prey hunted by T. opacum.

T. opacum in the same habitat in this park, but were lower than those obtained for this same species in southeastern Brazil. Camillo and Brescovit (1999a) do not discuss these results but comment that Genaro et al. (1989) obtained, for Trypoxylon subimpressum Smith in Cuba, values that were similar to those obtained in their study.

Trypoxylon rogenhoferi Kohl also showed a preference towards spiders of the family Araneidae (Camillo and Brescovit, 2000). This species captured 55 species of spiders, with Alpaida being the most collected genus. The amplitude of the reproductive niche for this species in the three studied regions was $\mathrm{H}^{\prime}=1.25, \mathrm{H}^{\prime}=1.30$ and $\mathrm{H}^{\prime}=1.29$ and, according to these authors, were not significantly different. When compared to those obtained for T. lactitarse in these same regions (Camillo and Brescovit 1999a) those of T. rogenhoferi were lower. According to Camillo and Brescovit (2000), these results indicate that these species do not compete in any significant manner for food in the three studied habitats.

A comparison between the spiders captured by Trypoxylon albonigrum Richards and by T. lactitarse and those found in the environment was carried out by Gonzaga and Vasconcellos-Neto (2005). Again, the genus Eustala was observed most frequently. Since the species composition and their abundance in the nests of these wasps were markedly different from the results obtained by visually searching the study area, the authors considered that they are extremely selective, and prey on relatively rare species while ignoring other abundant ones.

Coville (1986), while studying spider prey of Trypoxylon tridentatum Pakard from Arizona and California, observed that Araneidae and Theridiidae were the most frequent families. According to the author, the relative proportions of the two families varied from one locality to another, but in general araneids were more abundant. According to Coville (1987) this might result from females hunting in different areas, exploring aggregations of spiders or becoming conditioned to certain types of spiders or hunting behaviour. In the nests of Trypoxylon tenoctitlan Richards, individual differences were observed, but a variation was observed between the nests (Coville, 1987). For Araújo and Gonzaga (2007) an individual variation in the use of resources, as is the case of T. albonigrum, is possibly a result of learning trade-offs associated with prey searching and/or handling times. This wasp preys on spiders showing a wide range of defensive tactics that, in turn, might require different skills from the wasp to locate and subdue their prey. Thus, the individual would enhance its foraging efficiency and despite its individualism, the population as a whole becomes generalist.

Another result obtained in our study and that has also been observed for other Trypoxylon species (Rehnberg, 1987; Genaro and Alayón, 1994; Camillo and Brescovit, 1999a, 1999b; Gonzaga and Vasconcellos-Neto, 2005; Buschini et al., 2008) was the low number of adult spiders in T. opacum nests. A total of 900 juvenile spiders, 107 females and 46 males were captured by T. opacum, the number of juveniles being significantly higher than that of males and females. For some authors this pattern might be a consequence of the lower ability of the wasps to locate individuals moving on vegetation. Adult araneid males leave their webs to search for females, thereby reducing their exposure to predators that might use the web as a visual sign for approximation (Gonzaga and Vascocellos-Neto, 2005; Polidori et al., 2007). In contrast to our study, Gonzaga and Vasconcellos-Neto (2005) observed, in some periods, that the number of captured females was higher than juveniles. For Rehnberg (1987), females could be preferred for their higher content in lipids compared to juveniles and adult males. It is possible that the high number of juveniles in T. opacum's diet is related to the facility of transportation of smaller stages and also with the lower risks they present to the wasps, since adults spiders can catch wasps (Brockmann and Graffen, 1992).

Acknowledgements - Parcial support was provided by Fundação Araucária (The State of Paraná Research Foundation) and UNICENTRO (Guarapuava - PR, Brazil).

\section{References}

ARAÚJO, AS. and GONZAGA, MO., 2007. Individual specialization in the hunting wasp Trypoxylon (Trypargilum) albonigrum (Hymenoptera, Crabronidae). Behavioral Ecology and Sociobiology, vol. 61 , no. 12 , p. $1855-1863$. 
AYRES, M., AYRES Jr., M., AYRES, DL. and SANTOS, AS., 2003. BioStat 3.0: aplicações estatísticas nas áreas das ciências biológicas e médicas. Brasília, DF: Sociedade Civil Mamirauá, CNPq.

BLACKLEDGE, TA., CODDINGTON, JA. and GILLESPIE, RG., 2003. Are three-dimensional spider webs defensive adaptations? Ecology Letteres, vol. 6, no. 1, p. 13-18.

BROCKMANN, HJ. and GRAFEN, A., 1992. Sex ratios and life-history patterns of solitary wasp, Trypoxylon (Trypargilum) politum (Hymenoptera: Sphecidae). Behavioral Ecology and Sociobiology, vol. 30, no. 1, p. 7-27.

BUSCHINI, MLT., BORBA, NA. and BRESCOVIT, AD., 2008. Patterns of prey selection of Trypoxylon (Trypargilum) lactitarse Sausurre (Hymenoptera: Crabronidae) in southern Brazil. Brazilian Journal of Biology, vol. 68, no. 3, p. 519-528.

BUSCHINI, MLT. and WOISKI, TD., 2008. Alpha-beta diversity in trap-nesting wasps (Hymenoptera: Aculeata) in southern Brazil. Acta Zoologica (Stockholm), vol. 89, no. 4, p. 351-358.

BUSCHINI, MLT. and WOLFF, LL., 2006. Notes on the biology of Trypoxylon (Trypargilum) opacum Brèthes (Hymenoptera, Crabronidae) in southern Brazil. Brazilian Journal of Biology, vol. 66 , no. 3, p. $907-917$

BUSCHINI, MLT., NIESING, F. and WOLFF, LL., 2006. Nesting biology of Trypoxylon (Trypargilum) lactitarse Saussure (Hymenoptera, Crabronidae) in trap-nests in southern Brazil. Brazilian Journal of Biology, vol. 66, no. 3, p. 919-929.

CAMILLO, E. and BRESCOVIT, AD., 1999a. Spiders (Araneae) captured by Trypoxylon (Trypargilum) lactitarse (Hymenoptera: Sphecidae) in southeastern Brazil. Revista de Biología Tropical, vol. 47 , no. $1-2$, p. $151-162$.

CAMILLO, E. and BRESCOVIT, AD., 1999b. Aspectos biológicos de Trypoxylon (Trypargilum) lactitarse Saussure e Trypoxylon (Trypargilum) rogenhoferi Kohl (Hymenoptera: Sphecidae) em ninhos armadilhas, com especial referência a suas presas. Anais $d a$ Sociedade Entomológica do Brasil, vol. 28, no. 2, p. 251-261.

CAMILLO, E. and BRESCOVIT, AD., 2000. Spider prey (Araneae) of Trypoxylon (Trypargilum) rogenhoferi (Hymenoptera: Sphecidae) in southeastern Brazil. Revista de Biología Tropical, vol. 48 , no. $2-3$, p. $647-656$.

CLOUDSLEY-THOMPSON, JL., 1995. A review of the antipredator devices of spiders. Bulletin of the British Arachnological Society, vol. 10, no. 3, p. 81-96.

COVILLE, RE., 1981. Biological observations on three Trypoxylon wasps in the subgenus Tripargilum from Costa Rica: T. nitidiu schultessi, T. saussurei and T. lactitarse (Hymenoptera: Sphecidae). Pan-Pacific Entomologist, vol. 57, no. 2, p. 332-340.

COVILLE, RE., 1986. Spider prey of Trypoxylon tridentatum (Hymenoptera: Sphecidae) from Arizona and California. PanPacific Entomologist., vol. 62, no. 2, p. 119-120.

COVILLE, RE., 1987. Spider-hunting sphecid wasps. In NENTWIG, W. (Ed). Ecophysiology of spiders. New York: Springer. p. 309-318.
EIGENBRODE, SD., RAYOR, L., CHOW, J. and LATTY, P., 2000. Effects of wax bloom variation in Brassica oleracea on foraging by a vespid wasp. Entomologia Experimentalis et Applicata, vol. 97, no. 2, p. 161-166.

EVANS, HE., 1963. Predatory wasps. Scientific American, vol. 208, no. 4, p. 144-154.

GARCIA, MVB. and ADIS, J., 1995. Comportamento de nidificação de Trypoxylon (Trypargilum) rogenhoferi Kohl (Hymenoptera, Sphecidae) em uma floresta inundável de várzea na Amazônia Central. Amazoniana, vol. 13, no. 3-4, p. 259-282.

GENARO, JA. and ALAYÓN, G., 1994. Las presas (Araneae) de Trypoxylon (Trypargilum) subimpressum (Hymenoptera: Sphecidae) em Cuba. Revista de Biología Tropical, vol. 42, no. $1-2$, p. $353-356$

GENARO, JA., SANCHEZ, C.S. and ALAYÓN,G., 1989. Notas sobre la conducta de nidificación de Trypoxylon (Trypargilum) subimpressum (Hymenoptera: Sphecidae). Caribbean Journal of Science, vol. 25, no. 1, p. 228-229.

GONZAGA, MO. and VASCONCELLOS-NETO, J., 2005. Orbweb spiders (Araneae: Araneomorphae; Orbiculariae) captured by hunting-wasps (Hymenoptera: Sphecidae) in an area of Atlantic Forest in southeastern Brazil. Journal of Natural History, vol. 39, no. 31, p. 2913-2933.

JONES, MT., CASTELLANOS, I. and WEISS, MR., 2002. Do leaf shelters always protect caterpillars from invertebrate predators? Ecological Entomology, vol. 27, no. 6, p. 753-757.

LUDWIG, JA. and REYNOLDS, JF., 1988. Statistical ecology: a primer on methods and computing. New York: John Wiley and Sons.

MANTEL, N., 1967. The detection of disease clustering and a generalized regression approach. Cancer Research, vol. 27, no. 1, p. 133-153.

O’NEILL, KM., 2001. Solitary wasps. Behavior and natural history. London: Comstock Publishing Associates.

O'BRIEN, MF., 1982. Trypargilum tridentatum (Packard) in trap nests in Oregon (Hymenoptera: Sphecidae: Trypoxylinae). Pan-Pacific Entomologist, vol. 58, no. 2, p. 288-290.

PALMA, S., 1975. Contribución al estudio de los sifonoforos encontrados frente a la costa de Valparaiso. Aspectos ecológicos. In II Simpósio Latino americano sobre Oceanografia Biológica. Venezuela: Univ. D’Oriente. P. 119-133.

POLIDORI, C., BOESI, R., ISOLA, F. and ANDRIETTI, F., 2005. Provisioning patterns and choice of prey in the digger wasp Cerceris arenaria (Hymenoptera: Crabronidae): the role of prey size. European Journal of Entomology, vol. 102, no. 4, p. 801-804.

REHNBERG, BG., 1987. Selection of spider prey by Trypoxylon politum (Say) (Hymenoptera: Sphecidae). Canadian Entomologist, vol. 119 , no. 2 , p. 189-194

WEAVING, AJS., 1988. Prey selection in several sympatric species of Ammophila W. Kirby (Hymenoptera: Sphecidae) in southern Africa. Annals of the Cape Provincial Museums (Natural History), vol. 16, no. 1, p. 327-349. 